
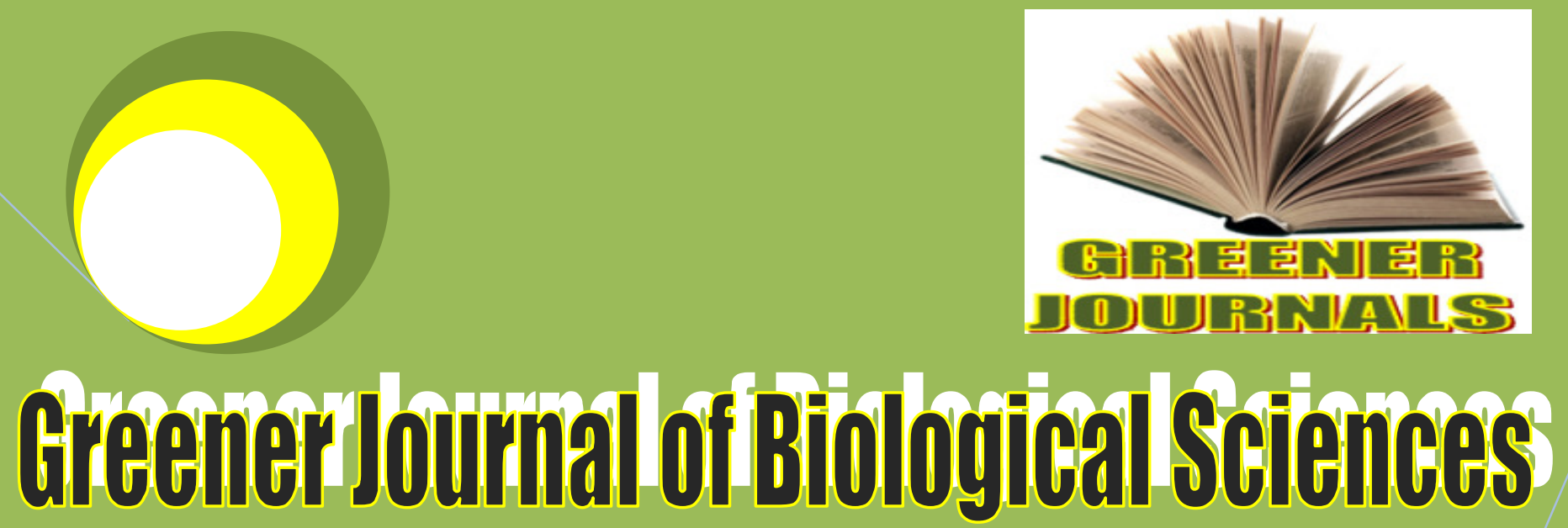

ISSN: 2276-7762 Impact Factor 2012 (UJRI): 0.7361 ICV 2012: 5.99

\title{
Diversity and \\ Condition Factor of \\ Fish Species of Dadin Kowa Dam, Gombe State, Nigeria
}

By

Nazeef S. Abubakar U. M. 


\title{
Diversity and Condition Factor of Fish Species of Dadin Kowa Dam, Gombe State, Nigeria
}

\author{
*Nazeef S. and Abubakar U. M. \\ Department of Biological Sciences, Gombe State University, P. M. B. 127, Gombe, Nigeria. \\ *Corresponding Author’s Email: snaxyph@yahoo.com
}

\begin{abstract}
The diversity and condition factor of fish species of Dadin Kowa Dam were studied over a period of six (6) months (February to July, 2013). Out of the fifteen fish species identified, family Mormyridae had the highest number of three (3) species, followed by families Bagridae and Characidae with two (2) species representing each. Hydrocynus brevis (family Characidae) ranked $\mathbf{2 2 . 1 4 \%}$, then Labeo senegalensis (family Cyprinidae), Mormyrus senegalensis (family Mormyridae), Schilbe mytus (family Schilbedae) with $17.40 \%, 17.01 \%$ and $13.05 \%$ of the total fish species identified. $60 \%$ of the fish species identified had their condition factors within the range of 0.1 to 1.0 ; whereas the remaining $40 \%$ of the fish had the condition factor greater than 1.0. Adequate measures need to be taken into account as most of the landed catches were juveniles and sub-adult which could render the water body less productive in a near future.
\end{abstract}

Keywords: Diversity, Condition factor, fish species, Dadin Kowa Dam.

\section{INTRODUCTION}

Fishing practice is attracting a lot of focus because it contributes significantly to the world proteins requirement (Moses, 1990). Fish is a high quality food, its content of protein matter is important. It is rich in vitamins and contains variable quantities of fat, and calcium for human health (Moses, 1990). The protein is first class and inexpensive and its composition and consumption is desirable (Moses, 1990).

Nigeria is blessed with abundant natural water bodies with abundant fish resources. Nigerian freshwater bodies are the richest in West Africa in terms of fish abundance (Meye and Ikomi, 2008). The fish resources, apart from being a major source of high quality animal protein for man, provide several socio-economic values as sources of job opportunities and raw material for some industrial activities as well as recreational purposes (Yakub, 2012).

Nigeria's populations live near water bodies such as lakes, lagoons, reservoirs, rivers, swamps and coastal lagoons. Many depend heavily on the resources of such water bodies for their main source of animal protein and family income (Abubakar et al., 2006).

Ita (1993) reported 268 different species in 34 well known Nigerian freshwater rivers, lakes, reservoirs, which constitute about $12 \%$ of Nigeria's total surface area of about $98,185,000$ hectares. However, according to Jamu and Ayinla (2003), the yields of most of these inland waters are generally on the decline due to environmental degradation such as water pollution and improper or poor management of fisheries resources. Environmental Protection Agency (EPA) recommended species richness and relative abundance as ecological risk assessment in aquatic ecosystem (EPA, 2007). Ita (1993) reported an estimated 230 species in Nigerian rivers.

Odo et al (2009) reported an estimated fifty two (52) fish species belonging to seventeen (17) families from Anambra River, Nigeria. The fisheries and fish resources of Nigeria are not only of considerable economic importance but they are also making a significant contribution to national food security and as well providing a major source of employment in rural areas. The fish stock diversities are directly dependent on the quality and quantity of water resources in the country (Bolorunduro, 2003).

Condition factor is a useful index for the monitoring of feeding intensity, age, and growth rates in fish (Oni et al., 1983). Condition factor is strongly influenced by both biotic and abiotic environmental conditions and can be used as an index to assess the status of the aquatic ecosystem in which fish live (Afamdi, 2005).Condition factors of different tropical fish species were investigated and reported by Bakare (1970), Saliu (2001) Lizama et al (2002) and similar studies particular to cichlid fish including, Siddiqui (1977), Welcomme (1979), Fagade (1978, 1983), Dadzie and Wangila (1980), Arawowomo (1982) and Oni et al., (1983).

This research is aimed at determining the diversity and condition factor of fish species in Dadin Kowa Dam. 


\section{MATERIALS AND METHODS}

Dadin Kowa Dam is located 5km North of Dadin Kowa village (about 37km from Gombe town, along Gombe-Biu road) in Yamaltu Deba local Government Area of Gombe State (Figure 1). The area lies within longitude $11^{\circ} 30^{\prime} \mathrm{E}$ and $11^{\circ} 32^{\prime} \mathrm{E}$, and Latitude $10^{\circ} 17^{\prime}$ and $10^{\circ} 18^{\prime} \mathrm{N}$ of the equator (UBRDA, 1980).

Fish sampling were carried out fortnightly from February to July, 2013 by using gillnets of different mesh sizes $(2.0,2.5,3.0$ inches). 10\% formalin was used for sample preservation before been transported to the laboratory where the fish species identification was performed with the aid of reference materials (Holden and reed, 1972., Anthony, 1982., Babatunde and Raji, 1998). Samples were weighed to the nearest $0.1 \mathrm{~g}$ using weighing balance. The standard lengths were measured to the nearest $0.1 \mathrm{~cm}$ on a measuring board. Fulton's condition factor was calculated from the expression (Bagenal, 1978)

$\mathrm{K}=100 \mathrm{~W} / \mathrm{L}$

Where $\mathrm{W}$ is the whole body weight in grams and $\mathrm{L}$ is standard length in centimetres.

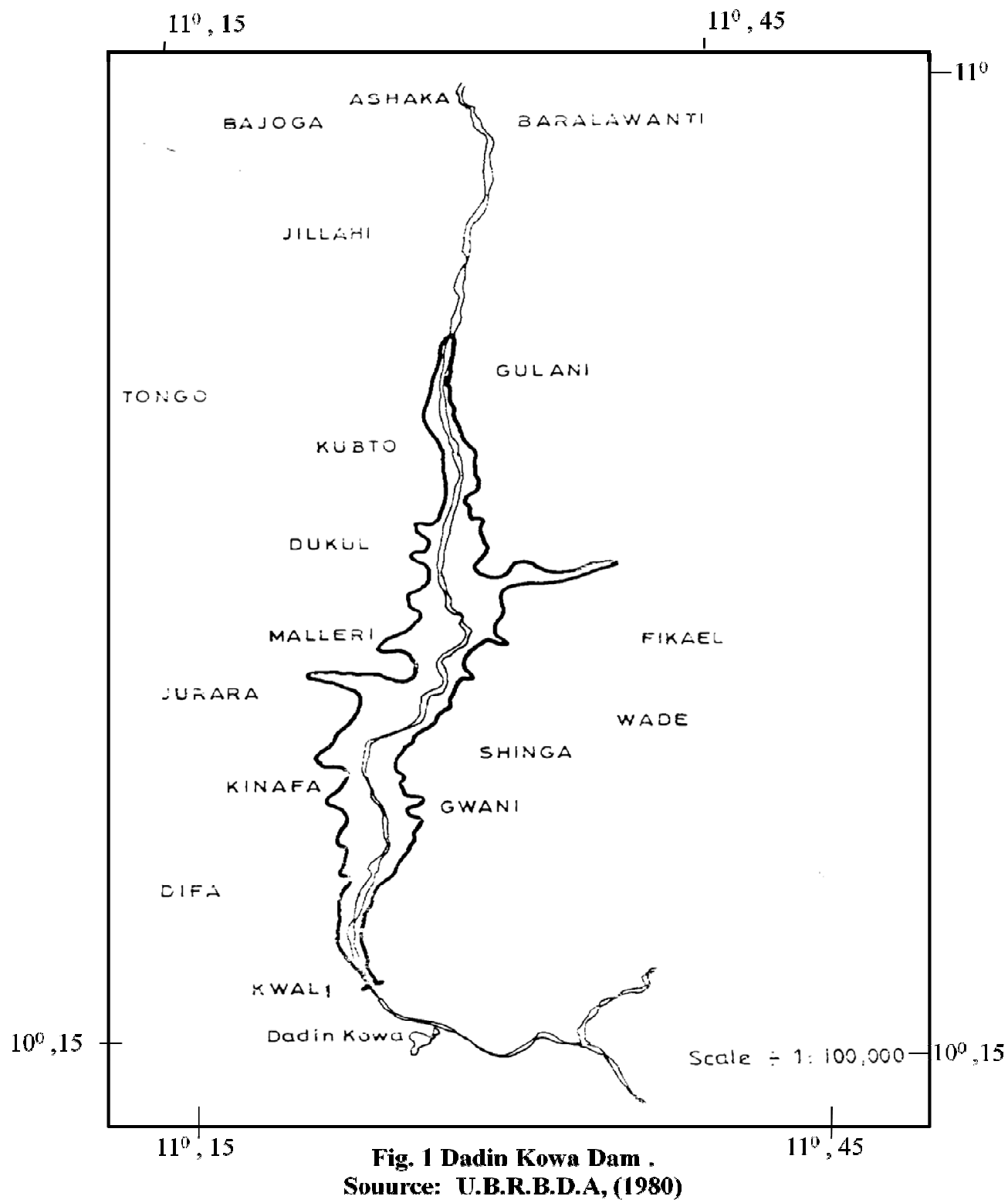




\section{RESULTS}

The study reveals that fifteen (15) species representing eleven (11) families has been identified (Table 1), it also shows that family Mormyridae had the highest number of three (3) species, followed by Bagridae and Characidae with two (2) species representing each.

Table two (2) contains the percentage composition of fish species identified in Dadin-Kowa in Dadin Kowa Dam. The table shows that Hydrocynus brevis, Labeo senegalensis, Mormyrus senegalensis, and Schilbe mystus had $22.14 \%, 17.48 \%, 17.01 \%$, and $13.05 \%$ of the total fish species identified. This is then accompanied by Momyrus rume, Bagrus bayad, Clarias lazera, and Synodontis ocellifer with $6.25 \%, 5.12 \%, 4.66 \%$, and $3.96 \%$ of the total fish species identified. The remaining fish species had less than $3.0 \%$ of the total fish species identified.

TABLE 1: FISH SPECIES IDENTIFIED IN DADIN-KOWA DAM

\begin{tabular}{|c|c|}
\hline Family & Species identified \\
\hline Bagridae & $\begin{array}{l}\text { Bagrus bayad } \\
\text { Bagrus docmac }\end{array}$ \\
\hline Characidae & $\begin{array}{l}\text { Alestes leuciscus } \\
\text { Hydrocynus brevis }\end{array}$ \\
\hline Cichlidae & Oreochromis niloticus \\
\hline Citharinadae & Citharinus citharus \\
\hline Claridae & Clarias lazera \\
\hline Claroteidae & Auchenoglanis occidentalis \\
\hline Cyprinidae & Labeo senegalensis \\
\hline Mochokidae & Synodontis ocellifer \\
\hline Mormyridae & $\begin{array}{l}\text { Mormyrus sanguilloides } \\
\text { Mormyrus rume } \\
\text { Mormyrus senegalensis }\end{array}$ \\
\hline Schilbedae & Schilbe mystus \\
\hline Polypteridae & Polypterus ansorgei \\
\hline
\end{tabular}

TABLE 2: PERCENTAGE COMPOSITION OF FISH SPECIES IDENTIFIED IN DADIN-KOWA DAM

\begin{tabular}{lll}
\hline Fish species & Number identified & Percentage (\%) \\
\hline Alestes leuciscus & 12 & \\
Auchenoglanis occidentalis & 06 & $2.79 \%$ \\
Bagrus bayad & 22 & $1.39 \%$ \\
Bagrus docmac & 04 & $5.12 \%$ \\
Citharinus citharus & 06 & $0.93 \%$ \\
Clarias lazera & 20 & $1.39 \%$ \\
Hydrocynus brevis & 92 & $4.66 \%$ \\
Labeo senegalensis & 72 & $22.14 \%$ \\
Mormyrus anguilloides & 02 & $17.48 \%$ \\
Mormyrus rume & 28 & $0.46 \%$ \\
Mormyrus senegalensis & 73 & $6.52 \%$ \\
Oreochromis niloticus & 12 & $17.01 \%$ \\
\end{tabular}




\begin{tabular}{llll} 
& Polypterus ansorgei & 01 & $0.23 \%$ \\
& Schilbe mystus & 56 & $13.05 \%$ \\
& Synodontis ocellifer & 17 & $3.96 \%$ \\
\hline Total & & $\mathbf{4 2 9}$ & $\mathbf{1 0 0 \%}$ \\
\hline
\end{tabular}

The weight and length of the fish species identified in Dadin-Kowa Dam is presented in Table 3 . The table also shows the relationship between the weight and length (condition factor) of the fish species identified.

Table 4 shows the percentage $(\%)$ condition factor $(k)$ of the fish species identified in Dadin-Kowa Dam. The table revealed that Synodontis ocellifer, Oreochromis niloticus, Polypterus ansorgei, and Schilbe mystus had $11.47 \%$, $10.20 \%, 9.75 \%$, and $8.48 \%$ respectively, followed by Hydrocynus brevis (7.39\%), Citharinus citharus $(7.27 \%)$, Mormyrus senegalensis (6.37\%), Alestes leuciscus (6.02\%), Mormyrus rume (5.42\%) and Bagrus docmac (5.10\%). The remaining fish species had less than $5.0 \%$ (Table 6 ). The table also reveals that $40 \%$ (6 species out 15 ) of the fish species had their $\mathrm{K}$ values above 1.0 , while the remaining percent $(60 \%)$ had their $\mathrm{K}$ values from 0.1 to 1.0 respectively.

\section{TABLE 3: WEIGHT-LENGTH RELATIONSHIP OF FISH SPECIES IDENTIFIED IN DADIN-KOWA DAM}

\begin{tabular}{llll}
\hline Fish species & Weight(g) & Length(cm) & Condition factor(K) \\
\hline Alestes leuciscus & 215 & 28 & 0.95 \\
Auchenoglanis occidentalis & 315 & 35 & 0.73 \\
Bagrus bayad & 327 & 38 & 0.59 \\
Bagrus docmac & 100.5 & 23 & 0.80 \\
Citharinus citharus & 202 & 26 & 1.14 \\
Clarias lazera & 189 & 29 & 0.77 \\
Hydrocynus brevis & 32 & 14 & 1.16 \\
Labeo senegalensis & 25 & 15 & 0.70 \\
Mormyrops anguilloides & 520.5 & 41 & 0.75 \\
Mormyrops rume & 309 & 33 & 0.85 \\
Mormyrus senegalensis & 275 & 30 & 1.00 \\
Oreochromis niloticus & 54 & 15 & 1.60 \\
Polypterus ansorgei & 104 & 19 & 1.51 \\
Schilbe mystus & 23 & 12 & 1.33 \\
Synodontis ocellifer & 229 & 23 & 1.80 \\
\hline Total & $\mathbf{2 8 2 4}$ & &
\end{tabular}




\section{TABLE 4: PERCENTAGE CONDITION FACTOR (K) OF FISH SPECIES IDENTIFIED IN DADIN-KOWA DAM} Fish species Condition factor

(K)

Alestes leuciscus

0.95
Percentage condition

Alestes leuciscus

0.73 factor (\%)

Auchenoglanis occidentalis

0.59

$4.65 \%$

Bagrus bayad

0.80

$3.76 \%$

Bagrus docmac

1.14

$5.10 \%$

Citharinus citharus

0.77

$7.27 \%$

Clarias lazera

1.16

$4.91 \%$

Hydrocynus brevis

0.70

$7.39 \%$

Labeo senegalensis

0.75

$4.46 \%$

Mormyrops anguilloides

0.85

$4.78 \%$

Mormyrops rume

1.00

$5.42 \%$

Mormyrus senegalensis

1.60

$6.37 \%$

Oreochromis niloticus

1.51

$10.20 \%$

Polypterus ansorgei

1.33

$9.75 \%$

Schilbe mystus

1.80

$8.48 \%$

Synodontis ocellifer

$11.47 \%$

\section{DISCUSSION}

The result shows that the Dam has a rich Ichthyofauna complex with fifteen (15) species and eleven (11) families compared with other water bodies where similar studies had been carried out; for instance in Gubi reservoir of Bauchi State, only seven (7) family were identified (Oguzie, 1982). The result of this study agrees with that of many researchers which include (Ekeanyanwu, 1980) in river Delmi Jos, where seven (7) genera were identified. (Anthony et al., 1986) recorded four species in Auree reservoir near Plateau state. Eleven species were identified in lake Botsumtwi, Ghana (Whyte, 1975). Abdullahi (2005) reported 26 species identified in River Benue around Boronji area. Dankishiya (1991) identified 31 species in Lake Geriyo. Akanbi (2011) identified 26 species in Ogun estuary, Ogun state.

From the condition factor of the fifteen (15) fish species examined, it was observed that $60 \%$ (9 species out of 15) fish species had their $\mathrm{K}$ values within the range of 0.1 to 1.0 , a total of $40 \%$ of fish species had condition factor greater than 1.0. According to Lagler (1958), it has been found out that the value of $\mathrm{K}$ is not constant for individuals; species, populations, but is subject to wide variations for fish of average natural conditions. The K-factor should be equal to 1 , while $<1$ and $>1$ indicate below and average conditions respectively. Wade (1992) stated that condition factor greater or equal to one is good. This suggests that the condition factor for Dadin-Kowa Dam compared to lagoons affected by season and salinity was favourable to most of the species in the Dam. 


\section{REFERENCES}

Abdullahi M. (2005): Diversity and abundance of fish species in River Benue-Boronji area. B.

Abubakar K.A., Haruna, A.B., and Ladu, B.M.B (2006): An assessment of the physiochemical parameters and productivity of Lake Geriyo, Yola, Adamawa State, Nigeria. Biological and Environmental sciences Journal for the Tropics 3(1):18-23

Afamdi Anene (2005): Condition factor of four Cichlid species of a man-made Lake in Imo State, Southeastern Nigeria. Turkish Journal of Fisheries and Aquatic Sciences 5:43-47.

Akanbi, A.A. (2011): Catch assessment, fish species diversity and abundance in Ogun estuary, Ogun state, Nigeria. B.Sc. Project. University of Agriculture Abeokuta, Nigeria. Pp 28

Anthony, A. O. (1982): Identification of Nigerian fresh water fishes. Pp 4-18.

Anthony, A. O., Enerience G., and Ufodike, E.B.C (1986): Studies on the fish fauna of Auree reservoir Plateau State. Nigeria Journal of Applied Fisheries and Hydrobiology, volume 1. Pp15-16.

Arawomo, G. A. O. (1982): The growth of Sarotherodon niloticus (L) in open reservoir, proceedings of the $2^{\text {nd }}$ Annual Conference of the Fisheries Society of Nigeria, University of lle-Ife, Ile-Ife, Nigeria: 221-227.

Babatunde, D.O and Raji, A. (2004): Field guide to Nigeria freshwater fishes. Federal College of Freshwater Fisheries Technology. New Bussa Nigeria. 104pp.

Bakare O. (1970): Bottom deposits as food of inland freshwater fish. In: S. A. Visser (Ed) Kainji Lake studies Vol. 1: Ecology. Published for the Nigerian Institute of Social and Economic Research, Ibadan: 89-95.

Begenal, T. B. (1978): Aspect of fish fecundity. In: S. D. Gerking (Ed) Ecology of Freshwater fish production. Blackwell scientific publications, Oxford: 75-101.

Bolorunduro, P. I (2003): Post harvest loss assessment and adopting of disseminated technologies and artisanal fisheries of north western Nigeria. Ph.D. Thesis submitted at the faculty of science; Biological sciences department, University of Ibadan.

Dadzie, S. and Wangila, B. C. C. (1980): Reproduction Biology, length -weight relationship and relative condition of pond raised Tilapia zilli. (Gervaise) J. Fish. Biol., 17: 243-253.

Dankishiya, A.S. (1991): Species diversity of fishes in Lake Geriyo, Yola, Gongola State. B. Tech. Project, F.U.T. Yola. 72pp

Ekeanyanwu, A.A (1980): A survey of macro invertebrates and fish fauna in relation to water quality in Delmi River Jos. B.Sc. Thesis Zoo dept. Uni-Jos Nigeria.

Environmental Protection Agency (EPA) (1994): National Guidance: Guidance for Assesing chemical contaminant data for use in fish Advisories. Volume II. Risk Assesement and fish consumption limits. $3^{\text {rd }}$ edn., Office of water, Philadelphia.

Fagade, S. O. (1978) : On the Biology of Tilapia guineensis (Dumeril) from the Lagos lagoon, Lagos State, Nigeria. Nigerian Journal of Science, 12: 2327.

Fagade, S. O. (1983) : The Biology of Chromotidotilapia guntheri from a small Lake. Arch Hydrobiol., 97: 60-72.

Holden, M and Reed, W. (1972): West African Fresh Water Fish. Pp 4-29.

Ita, E.O. (1993): Inland fishery resources of Nigeria. FAO, CIFA occasional paper no. 20, p120

Jamu, D.M and Ayinla, A.O. (2003): Potential for the development of agriculture in Africa. NAGA 26(3) 9-13

Lagler, K. F. (1956): Freshwater fishery biology. W.C Brown Company, Dubuque, IA.,USA, pp131-135, 159-166

Lagler, K. F. (1956): Freshwater fishery biology. W.C Brown Company, Dubuque, IA.,USA, pp131-135, 159-166

Lizama, M. De Los, A. P. and Ambroso, A. M. (2002): Condition factor in nine species of fish of the Characidae family in the upper Parana river floodplain, Brazil. Braz. J. Biolo.,62 (1): 113-124.

Meye, J. A. and Ikomi, R. B. (2012):A study on the fish fauna of Urie Creek at Igbide, Niger Delta. The Zoologist, 6: 69-80.

Moses, B. S. (1990): Distribution, ecology and fisheries potential of Nigerian Wetlands, In : E. V I Apkala and D. U. O Okali (Ed) Nigerian Wet Land UNESCO/MAB Portharcourt 35-46.

Odo, G. E., (2009): The fish fauna of Anambra river basin, Nigeria; species abundance and morphometry.

Oguzie, F. (1982): Aspect of feeding behavior and a chemotrypsin in the cichlid sarotherodon niloticus (Trewavas) in Gubi Reservoir Bauchi state. M.Sc. Thesis zoology department. Uni-Jos Nigeria. Pp30.

Oni, S. K., Olayemi, J. Y. and Adegboye, J. D. (1983): Comparative physiology of three ecologically distinct freshwater fishes, Alestes nurse Ruppell, Synodontis schall Bloch and S. Schneider and Tilapia zilli Gervaise. J. Fish Biol., 22: 105- 109.

Saliu, J. K. (2001): Observation on the condition factor of Brycinus nurse (Pisces: Cypriniformes, Characidae) from Asa Reservoir, llorin, Nigeria. Tropical Freshwater Biology, 10: 9-17.

Siddiqui, A. Q. (1977): Reproductive biology, length-weight relationship and relative condition of Tilapia leucosticte Naivasha, Kenya J. Fish Biol., 10:251-260. 
Tech. Thesis, Dept. of Biological Sciences. F.U.T Yola, pp15-16

Upper Benue River Basin Development Authority (UBRDA) 1980). Dadin-Kowa Resettlement Project, Draft final report. Vol. 2.

Yakub, A. S. (2012): A Survey of Fish fauna of lower Ogun Rivers at Ishasi, Ogun State, Western Nigeria. Continental J. Fisheries and Aquatic Science 6(2): 1-7.

Wade, J. W. (1985): Limnological and trace element studies in relation to primary productivity in two marine lakes. M.Sc. Thesis. University of Jos, Nigeria, 205pp.

Welcomme, R. L. (1979): Fisheries ecology of Floodplain Rivers. Longman Group Ltd., London, 317pp.

Whyte, S.A. (1975): Distribution, trophic relationship and breeding habits of the fish populations in a tropical lake Basin. (Lake Bosuntwi- Ghana). Reprinted from Journal zoo. London vol. 177. Pp 25-56. 